\title{
Monazite in \\ Atlantic Shore-Line Features
}

By Lincoln Dryden and Glen A. Miller

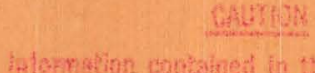

E. I.

da Pont de remours and Q..,
and Nat ional head Co.,

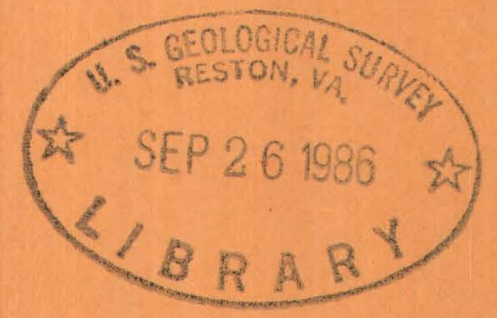

E.I. duPont de Nemours and Co., and Natronal head Co,

\section{Trace Elements Investigations Report 407}

UNITED STATES DEPARTMENT OF THE INTERIOR GEOLOGICAL SURVEY

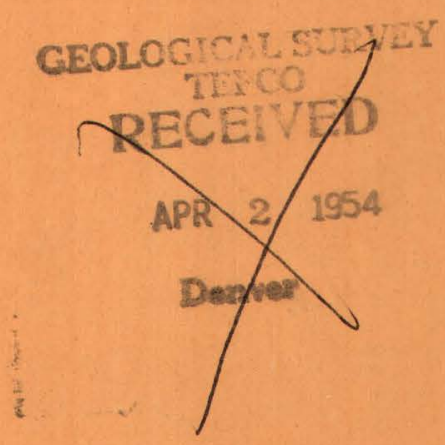


Geology and Mineralogy

This document consists of 29 pages.

Series A

UNITED STATES DEPARTMENT OF THE INTERIOR

GEOLOGICAL SURVEY

MONAZITE IN ATLANTIC SHORE-LINE FEATURES*

By

Lincoln Dryden and Glen A. Miller

January 1954

Trace Elements Investigations Report 407

\section{CAUTION}

Information contained in this document has been furnished in confidence by E. I. du Pont de Nemours and $\mathrm{Co}_{\circ}$. and National Lead $\mathrm{Co}_{\circ}$, and shall be handled accordingly within the USGS and AEC. The material herein shall not be published without the approval of $E_{0} \mathbb{I}_{0}$ du Pont de Nemours and $\mathrm{Co}_{\circ}$, and National Lead Co. and the U. S. Geological Survey.
This preliminary report is distributed without editorial and technical review for conformity with official standards and nomenclature. It is not for public inspection or quotation. 


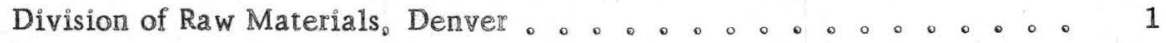

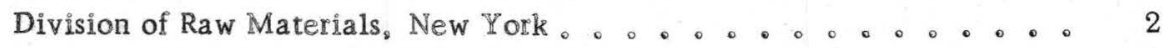

Division of Raw Materials, Salt Lake City...... . . . . . . 1

Division of Raw Materials, Washington . - . - . . - . . . 3

Exploration Division, Grand Junction Operations Office 。 . 。 . . 1

Grand Junction Operations Office.

U. S. Geological Survey:

Alaskan Geology Branch, Washington 。. . . 。 . . 。 . . 1

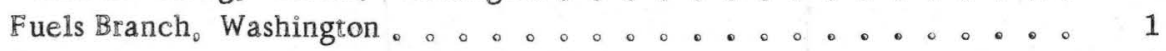

Geochemistry and Petrology Branch, Washington 。. . . 。 . 1

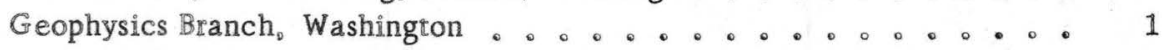

Mineral Deposits Branch, Washington 。…... 。 。 - . 1

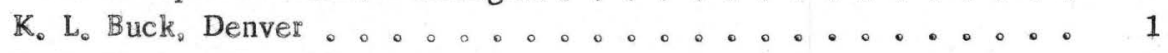

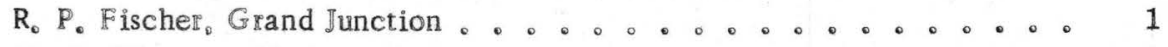

$M_{0} R_{\circ}$ Klepper, Washington 。. . . . . . . . . . . . . 1

$R_{c}$ A Laurence, Knoxville 。

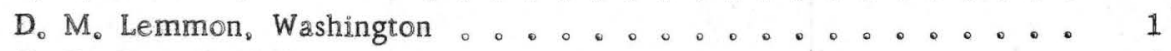

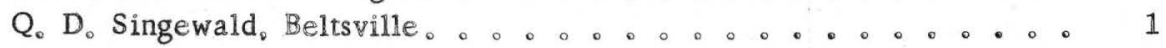

TEPCO, Denver 。.

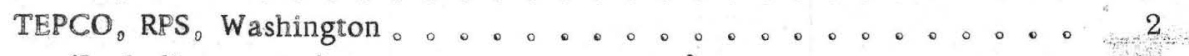

(Including master) 


\section{CONTENTS}

Abstract _. 0.0 .0 .0 .0 .0 .04

Introduction 0.0 .0 .0 .0 .0 .0 .0 .0 .0 .0 .0 .55

The Coastal Plain as a whole .............. 5

Area covered in this report ......... .0 .0 .05$

Nature of the Pleistocene deposits a . . . . . . . . 6

Previous work $0.0 .0 .0 .0 .0 .0 .0 \%$ ?

Present work 0.0 .0 .0 .0 .0 .0

Monazite in producing and potential ore bodies . . . . . . . . . 11

Producing ore bodies . $. . . . . .0 .0 .0 . . \circ . .11$

Trail Ridge ................. . . . 11

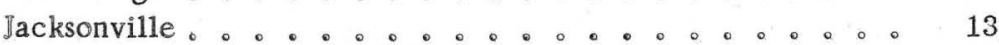

Potential ore bodies 。. . . . . . . . . . . . . . 14

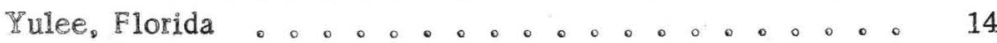

Folkston, Georgia - . . . . . . . . . . . . 15

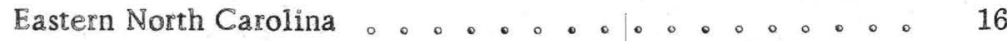

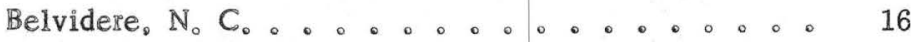

Aurora, $\mathrm{N}_{0} \mathrm{C}_{0} \ldots \ldots .0 .0 .0 .0 .018$

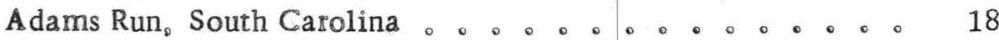

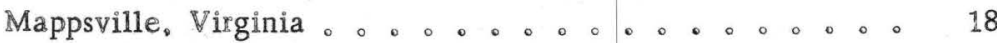

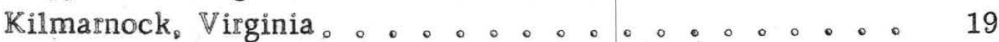

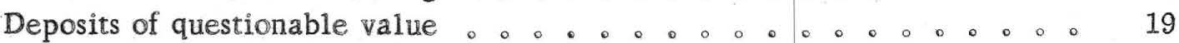

Pleistocene terraces $0 . .0 .0 .0 .0 .019$

Placers of low tenor 。. . . . . . . . . . 。 . 20

Recent beaches and dunes . . . . . . . . . . . . 20

Recent stream deposits ................. 21

Significance of titania content of ilmenite . . . . . . . . . . . . 22

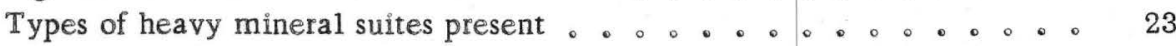

${ }^{\circ 0} \mathrm{Older}^{\circ 0}$ and ${ }^{\circ 0}$ younger ${ }^{\circ 0}$ suites .............. 24

Vertical range of the two suites ............. 25

Applications of titania content and type of suite.

Eastern North Carolina . o. . . . . . . . . . 26

Kilmarnock potential ore body _... . . 。 . . . . 26

Significance of Kilmarnock and Mappsville placers . . . . . . . 27

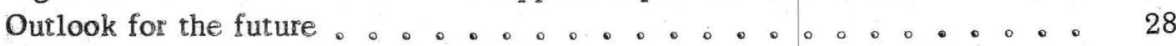

Literature cited ................ . . . . . 29

Unpublished report .................. .229

ILLUSTRATIONS

Figure 1. Coastal Plain - South Carolina to Florida . . . . . . 12

2. Coastal Plain Maryland to North Carolina. . . . . 17 


\section{MONAZITE IN ATLANTIC SHORE-LINE FEATURES}

By Lincoln Dryden and Glen A。 Miller

\section{A BS TRACT}

This report is a survey of present and potential production of monazite from part of the Maryland-Filorida section of the Atlantic Coastal Plain。

The part of the Coastal Plain covered here is the outer (shore-ward) half。 In this area, all the large heavy-mineral placers so far discovered occur in sand bodies that, by their shape, size, orientation, and lithology, appear to be ancient beaches, spits, bars, or dunes, Smaller placers have produced from recent shore-line features. The inner part of the Coastal Plain, to be treated in another report, is underlain generally by older rocks, ranging in age from Cretaceous to older Pleistocene。

Only two large heavy-mineral placers are now in production: at Trail Ridge, and near Jacksonville, both in Florida. Production is planned for the near future near Yulee, Fla two localities in eastern North Carolina Each of these three will produce monazite as a byproduct: the total new reserve for the three placers is about 33,000 tons of monazite.

In large heavy-mineral placers of this type, monazite has not been found to run more than about 1 percent of total heavy minerals. In some large placers, notably Trail Ridge, it is almost or completely lacking. No reason for its sporadic occurrence has been found in this investigation.

Two placers of potential economic value have been found by this project in Virginia one west and one east of Chesapeake Bay. Neither is of promise for monazite production, but if they serve to open up exploration or production in the area there is a chance for monazite as a byproduct from other placers.

A discovery of considerable scientific interest has to do with the occurrence of two different suites of heavy minerals in the Coastal Plain, at least south of Virginia. One。 an "older" suite, lacks epidote. hornblende, and garnet: this suite occurs in all older formations and in Pleistocene deposits lying above about 50 or 60 feet above sea level. The other "younger" suite contains these three minerals; it is restricted to recent beaches and streams, and to Pleistocene deposits at low altitudes. Monazite may occur with either of these suites. 


\section{OFFICIAL USE ONLY}

5

The percentage of titania $\left(\mathrm{TiO}_{2}\right)$ in ilmenite is of both scientific and economic interest. Ilmenite is by far the most sought-for mineral in present exploration, and whether it contains the "normal" 53 percent of titania or, as it commonly does in Florida, 60 percent, is often of decisive importance in its exploitation. The nature, time, and place of this "enrichment ${ }^{\circ}$ in titania has not been worked out。

The heavy-mineral industry of the area seems to give promise of considerable expansion in the near future, and a greater monazite production seems assured。

\section{INTRODUCTION}

\section{The Coastal Plain as a whole}

The Atlantic Coastal Plain, excluding that portion lying beneath the ocean, is a belt of country that varies in width from just a few miles near New York City to about 200 miles in Georgia; it is generally less than 200 or 300 feet in altitude and is characteristically an area of plains and low hills. For the most part it is underlain by unconsolidated sedimentary rocks which range in grain size from pebbles to clays. It is bounded, along almost its entire length ${ }_{0}$ by the crystalline rocks of the Piedmont province; the boundary is the Fall Line.

\section{Area covered in this report}

In some parts of the report, reference will be made to the Coastal Plain as a whole but the principal attention will be given to the part underlain by the rocks of Pleistocene age. The area excluded is underlain by Cretaceous and Tertiary sediments, many of them marine, which lie more or less regularly one on the other。 The older rocks crop out at the inner margin of the Coastal Plain, and progressively younger. ones are arranged more or less like shingles, farther and farther from the Fall Line. From Georgia to North Carolina, this belt of older sediments makes up about half of the Coastal Plain, but northward the Pleistocene sediments reach much farther inland; from Maryland to New Jersey they underlie almost the entire surface of the Coastal Plain。 the older rocks appearing only where later erosion has removed the Pleistocene. 


\section{OFFICIAL USE ONLY}

A further subdivision of interest and importance may be made. Though the origin and nature of the Pleistocene deposits as a whole must be considered, all of the producing or potential ore bodies are found within large volumes of nearly pure sand; the study of these sand bodies has been one of the principal objects of the project. Recent beach and dune sands are but a special case within the general problem.

\section{Nature of the pleistocene deposits}

Only a few things about the origin and nature of the Pleistocene deposits are widely accepted: they are thin sheets, like veneers, lying unconformably on older rocks of various ages; they are mostly unsorted mixtures of pebbles, sand, and silt or clay; they lie in a belt roughly parallel and adjacent to the present coast: and those parts of the belt that are at very low altitudes seem to be largely marine in origin. Flint (1940) has given an excellent summary of the different viewpoints and of the problems involved。

One concept is that the Pleistocene sediments were laid down under marine waters, when the sea level stood some 300 feet higher than at present; at this early time the shore lay well inland in the Coastal Plain, possibly at or beyond the Fall line, Sediments, derived from older rocks lying to the west and northwest, were spread out on the sea floor, smoothing and leveling it, Later, sea level fell. At this new level, waves cut into the older deposits, forming a wavescut cliff or scarp. The former sea floor, underlain by the older sediments, now stood out, as a terrace. At the new, lower level, sediments accumulated on the sea floor. forming what was to be a new and lower terrace, separated from the higher and older one by a wave-cut scarp. Repeated relative falls of sea level and static land-sea relations at each level led to the formation of a series of terraces, separated by scarps; the terraces are progressively lower in elevation towards the present shore. These terraces have been named, and the supposed position of the shore line at the foot of each scarp has led to the association of an altitude with each terrace name. Under this concept, then, the Pleistocene deposits may be thought of as arranged in stair astep fashion, each tread being enormously wide and separated from the one below it by a riser (scarp), which is extremely small compared with the width of the treads (terraces). 
If it could be shown that this simple arrangement was true, the terrace names and altitudes would be used in this report, but because not only the ideas but even the facts are in question, very limited use will be made of them.

Other geologists believe that at least the Pleistocene deposits above 100 feet in altitude were formed under non-marine conditions, probably as stream deposits, laid down on flood plains or delta plains by shifting streams: an origin of this kind would explain the generally poorly sorted nature of the sediments, as well as their irregular cross-bedding and their rapid changes in lithology, both vertically and horizontally。 From this viewpoint, there are no scarps at higher altitudes, and none should be expected.

Whichever viewpoint is adopted, there is general agreement that many features below 100 feet. especially below 50 feet or so, have had a marine origin. Marine fossils have been found in a few places up to altitudes of about 30 feet. But more generally. geologists have resorted to the topographic expression of the deposits themselves to explain their mode of origin. Many of the deposits are fairly close to the present shore and are more or less parallel to ir. In addition, many of them are composed of rather clean sand and have a close resemblance in plan and profile to recent beaches, bars, or dunes. However。 similar features can occur at much higher altitudes, as is shown by the long spit-like or bar-like deposits at Trail Ridge, Fla 。 which reaches an altitude of about 250 feet: this feature, however is the most striking exception to the general rule.

\section{Previous work}

Atlantic shore-line features range from the recent beach and dunes to older and higher Pleistocene features, some of which may lie a hundred miles or more inland from the present coast. Certain aspects of the recent beaches and the geology of the older deposits have been covered in a number of papers which, for the most part, have only an indirect bearing on the subject of this report. Several important publica tions on heavy minerals of parts of the Coastal Plain provide useful background material.

Mertie (1949; 1951) is the only author who is interested primarily in the occurrence of monazite. Cannon (1950) takes up many of the general problems associated with placers and ore bodies in the Coastal Plain. 
Martens (1935) has described in considerable detail heavy minerals and other aspects of the beaches in the southeastern part of the Coastal Plain。 Although pertaining to another area, a paper by Beasley (1948) is of great interest because it seems to provide a method for the formation of beach placers and of the dune concentrations derived from them.

Mertie ${ }^{0}$ s conclusions are directly applicable to the present work and therefore are summarized here. He collected 56 samples from the Coastal Plain, for the most part from the unsorted and unwashed terrace materials. Heavy mineral percentages were found to be low - averaging 0.15 percent in South Carolina and 0.37 percent in Georgia: monazite percentages in the heavy minerals were 2.7 percent and 1.2 percent, respectively。Such tenors are far below present requirements for commercial operation。 Mertie believes that the proportion of monazite present has an inverse ratio to the percentage of total heavy minerals. He has presented his conclusions for the Coastal Plain in briefer form in a recent publication (1953)。

\section{Present work}

The work reported here differs from Mertie's in extent and scope. The Coastal Plain from Maryland to Florida has been examined in reconnaissance fashion. Of the 1,200 samples collected, 400 have been studied in a preliminary way for content and types of heavy minerals. It differs also in that the major effort has been devoted to finding, outlining, and studying large sand bodies; these sorted。 washed, and re-worked deposits may contain valuable heavy-mineral placers, such as the deposits now in production or from which production is planned in the near future. Most of these large bodies of relatively clean sand are elongate features that generally trend approximately parallel to the recent shore line, although some of them lie tens of miles from the present coast. They seem to have been formed by waves, currents, and winds when the shore line was higher and lay farther inland。By no means all large sand bodies of such character contain heavy-mineral placers of commercial or marginal grade, A large number of them have very low content and some of them are more cleanly washed and barren of heavy minerals than any recent beach or dune sand that we have examined. 
Early in the project it was realized that certain aspects of the problem of finding monazite in the southeastern Coastal Plain, such as theoretical problems of transportation, sorting, and sedimentation, gave little promise of yielding results in the near future. These questions have been left almost entirely out of considera tion, although their long-range study may prove to be of great value.

Attention has been given to the likelihood of finding placers rich in monazite but poor in other heavy minerals. The outlook, however, is definitely discouraging. All information available to us indicates that monazite will be found, if at all, as a minor constituent in heavy-mineral placers . This conclusion is based on experience alone: we see no theoretical reason why monazite should not form a high percentage of the heavy $\bullet$ mineral content. The major part of the work reported here has been the search for and the study of large heavy mineral placers in the hope that monazite might be found in byproduct quantity.

The method adopted by this project, and the only one known to us for finding heavy mineral ore bodies. consists of locating large sand bodies, and then testing them for heavy mineral content。 Mertie (1951. p $\left._{0} 27\right)$ states that ${ }^{\circ}$ The formations in which heavy minerals occurs are not indicated by the topography. and the sites of particular Pleistocene shore lines are no index of the occumpence of ore sands ${ }^{\circ}$ Our experience indicates the exact opposite to be true. All of the producing or known potencial ore bodies are in sands which have been fashioned, by waves, currents, or winds, into more or less distinct topographic features.

In du Pont's exploratory program consulting geologists prepared from topographic maps and aerial photographs a series of state maps on which were outlined the ${ }^{\circ p}$ promising features. These features were any elongate, usually higher strips that appeared to have been formed (or to be forming) as beaches, bars, or dunes. Usually such features consist in large part of fairly clean sand their heavy mineral content may range from almost nothing to that of commercial tenor (a minimum of about 4 percent in present operations). Hand-augering or jet-drilling in sand bodies of this character has revealed all the producing or potential ore bodies so far known.

Further, all such ore bodies, with two exceptions, are associated with what is loosely called the Pamlico shore line, between about 30 and 50 feet in altitude. Since du Pont and other companies have made such a thorough search for and testing of sand bodies at these and lower altitudes in the Southeastern States, the work 
of this project at the Pamlico level was extended northward into Virginia and Maryland ore bodies were discovered. In the Southeastern States, much of our work was carried out in features which seem to be associated with a former shore line at around 90 to 100 feet above sea level. Du Pont has recently discovered a body of commercial tenor at this altitude.

The evidence that ore bodies will be found only in such topographic features is in part negative for almost no drilling has been done in most of the wide, flat surfaces which make up much of the Coastal Plain. But from a limited amount of augering, and from numerous natural and artificial exposures it can be seen that such featureless surfaces are almost. always underlain by unsorted Pleistocene sediments, commonly mixtures of pebbles, sand sillt $_{0}$ and clay。 The heavy mineral content of such unsorted material has proven to be low. Virtually no exploration has been undertaken by this project or the companies except in areas where a definite topographic feature indicates the presence of a sand body: in some of these areas heavy mineral placers have been found. At the present time, all of the most promising topographic features have been examined at least briefly。 New methods of locating heavy-mineral concentrations are sorely needed。

Tracing heavy minerals of placers to their source offers several promising lines of attack It opens the possibility of finding placers in intermediate host rocks, and it may aid in the search for stream placers or bed-rock deposits in the ultimate source rock.

There has been considerable speculation but little proof as to the source of heavy minerals in Coastal Plain placers, other than that their ultimate source must have been crystalline rocks like granite, gneiss。 and schist. The present work strongly suggests that。 excepting recent beaches and very low altitude Pleisto cene features, the heavy minerals have been derived not directly from the Piedmont rocks but from erosion and reworking of various Coastal plain formations. This conclusion led to a search in these formations themselves; this work is incomplete。 but it suggests a possibility of finding placers in these intermediate source rocks.

Most recent beaches and low-level Pleistocene sand bodies apparently are being supplied or have been supplied directly from the Piedmont. Proof of this statement will be given later under a discussion of different types of heavy-mineral suites 
Various companies and individuals have helped with factual information, ideas, and suggestions. Outstanding in this respect is $\mathrm{Dr} \mathrm{J}_{0} \mathrm{~L}_{0}$ Gillson of $E_{0} \mathbb{I}_{\odot}$ du Pont de Nemours and Company who has given freely of his time and has made available a large number of maps, reports, and other data that du Pont

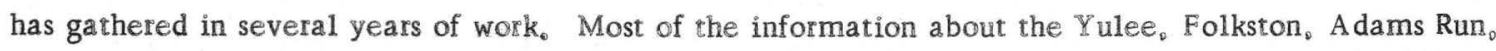
Aurora, and Belvidere placers has been furnished by $\mathrm{Dr}_{0}$ Gillson, $\mathrm{Mr}_{\circ} \mathrm{A}_{\circ} \mathrm{R}_{\circ}$ Reiser of the National Lead Company, and $\mathrm{Mr}_{0}$ Harry $\mathbb{B}_{0}$ Cannon, consulting geologist, have been helpful, although neither has been in a position to cooperate fully with the work of this project. This work is part of a program of exploration for radioactive raw materials that the $U_{0} S_{0}$ Geological Survey is conducting for the U. S. Atomic Energy Commission。

\section{MONAZITE IN PRODUCING AND POTENTIAL ORE BODIES}

\section{Producing ore bodies}

The only deposits whose current production is large are at Trail Ridge (du Pont) and east of Jacksonville (National Lead); both are in Florida (fig。1)。Other deposits in Florida whose production is small will not be considered further.

$$
\text { Trail Ridge }
$$

The topographic expression of the Trail Ridge deposit and the Trail Ridge ore body has been described in a number of publications, In the present account, only the virtual absence of monazite will be considered。

Occasional grains of monazite in the heavy mineral suite show that a source for this mineral was available when the ore body was formed. A simple explanation would be that great distance from the source was the cause of low monazite tenor. However, an equally great distance is necessary in the case of the Jacksonville ore body which has a content of about 1 percent - about as much monazite as has been found in the heavy minerals of any ore body of this size and character. 


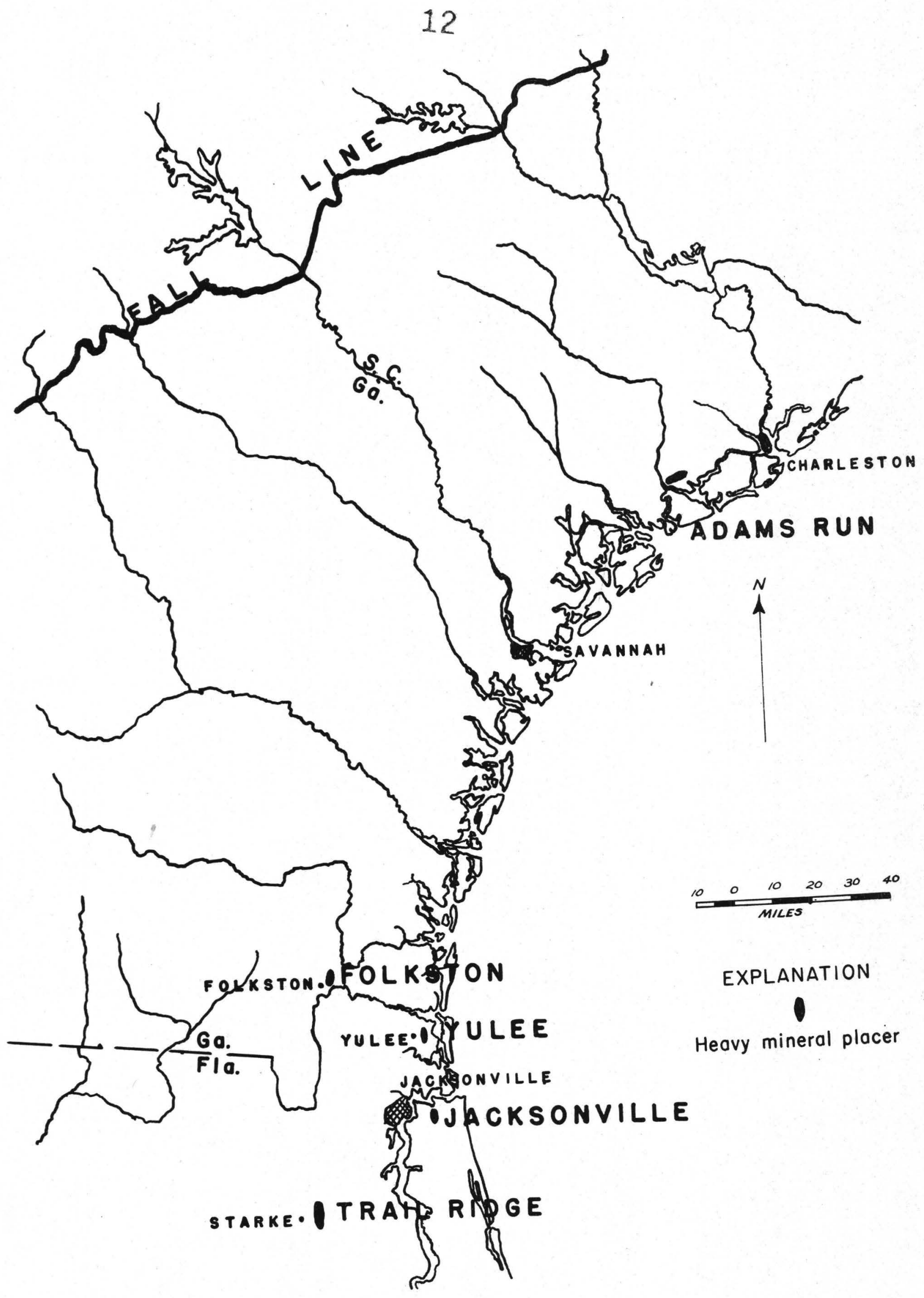

FIGURE I. COASTAL PLAIN--SOUTH CAROLINA TO FLORIDA 
In the Trail Ridge suite of minerals the grains are exceptionally large and have been unusually well rounded. The average grain size is larger than that of the monazite in most Coastal Plain rocks (exceptions: Tuscaloosa and McBean formations), and it may be that monazite was washed through (by-passed) while the other heavy minerals were being deposited. Also, monazite has comparatively low hardness and is friable and weak relative to the other principal species (ilmenite, zircon, staurolite, kyanite, sillimanite, tourmaline, and spinel) so that in the dune or beach environment in which the heavy minerals were extensively abraded and rounded. monazite may have been so reduced in size that it was virtually destroyed during sedimentation。

It should be made clear that while either one or both of the above explanations for low monazite tenor may be sufficient for this type of occurrence, the absense of monazite from certain other ore bodies cannot be explained in either of these ways. In this respect monazite is not unique for other heavy minerals manifest the same baffling behavior。

\section{Jacksonville}

The National Lead workings east of Jacksonville have been in production for a number of years and are also comparatively well known. The location and general setting are marked as "Strip Mine" in the north-central part of the Arlington, F1a。1:24,000 quadrangle。

This quadrangle illustrates in excellent fashion the use of topographic guides to explotation discussed before. In the western half of the sheet, there is no distinct trend, though there is a weak north-south alinement of certain features。 Similar flat surfaces without trends have been found to be underlain by unsorted materials, and in general this sort of topography is regarded as unfavorable in the search for heavy-mineral placers. But the eastern half of the sheet shows strong north-south orientation, of what appear to be old beaches or beach ridges, separated by lower, swampy swales。 The ridges are probably composed of well-sorted sand; such features are regarded as particularly favorable for heavy-mineral exploration。 It has been reported that potentially valuable placers have been found also in the south-central part of the map area on a prolongation of the producing trend ${ }^{\circ}$ at about 50 to 60 feet in altitude. 
Except for monazite, the heavy-mineral suite here is in general similar to that at Trail Ridge. though the grain size is smaller and rounding is much less perfect. Small percentages of epidote and

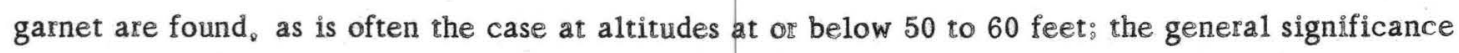
of this fact will be discussed later. Monazite tenor at present runs from about 0.7 percent to 1 percent of the heavy minerals. The monazite grains are small, almost all of them passing through the $1 / 8 \mathrm{~mm}$ sieve.

\section{Potential ore bodies}

A majority of the placers discussed under this heading have been discovered in commercial operations, but their existence apparently has not been made public. Two of the placers were discovered in the present work。

Two of these placers perhaps do not fall under the heading of "potential" present going ahead with plans for production: they are near Yulee in northeastern Florida, and near Folkston in southern Georgia。 In a third place, at Aurora in eastern North Carolina it is reported that National Lead is acquiring rights to mine。

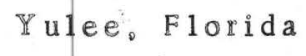

This ore body is located east and northeast of the small town of Yulee in section 6 of the St. Marys, Florida-Georgia, 1:62, 500 quadrangle. The general setting is similar to that of the ore body east of Jacksonville: low ridges alternating with swampy swales. However, at Yulee the maximum elevation is only about 30 feet and the north-south trend is not so strongly marked.

Nearasurface percentages of heavy minerals are comparatively low ${ }_{\mathrm{c}}$ and it was only through an extensive jet-drilling program that du Pont finally and recently established a tonnage and tenor sufficient for operation. Preliminary results showed that the ridges were high in heavy minerals, the swales comparatively poor。 This would suggest the formation of successive beach ridges, separated 
by small lagoons contaịning finer sediment poor in heavy minerals. Though the heavy-mineral suite is much like the one at Jacksonville, the lower altitude at Yulee is accompanied by the presence of about 10 percent of epidote.

Extensive sampling by du Pont has shown that the ore body here contains about 2,500,000 tons of heavy minerals, and of this total about 0,3 percent is monazite. This indicates a reserve of about 7.560 tons of that mineral.

Folkston, Georgia

Another ore body recently ourlined by du Pont ${ }^{\circ}$ s jet-drilling operations lies northeast of the town of Folkston, $\mathrm{Ga}_{\mathrm{e}}$ 。 in the central part of the western third of section 4 . Boulogne。 Georgia-Florida 1:62,500 quadrangle. It is about 2 miles long, in a north-south direction, and about a mile wide; the north-south trend of low, broad ridges and intervening swales near Folkston is poorly developed, as compared with the setting of the ore bodies at Pulee and east of Jacksonville. North and south of the Folkston ore body。 on trends as well developed as that containing the ore, only minor thicknesses of sand were found, with very small percentages of heavy minerals。

This Folkston discovery is rather instructive in that it was due largely to accident. An incorrectly identified sample led du Pont to believe that they had found high heavy mineral content here. and to return to the area for further work. The sire of the misidentified sample yiselded nothing of value, but additional holes put down nearby served to reveal the ore body, and a program of jet-drilling showed it to be of commercial size and tenor. One of the most significant things about this body is that it is the first one found at the 90 -foot level; indeed it is the first placer of commercial grade found between the ones at 50 feet or lower, nearer the coast, and the Trail Ridge ore at about 200 feet。 However, it is not to be immediately assumed that this level will be widely productive, for much of the exploratory work of this project from Virginia to Georgia has been particularly directed at features at the same altitude; so far the results of our work on deposits at this level have been negative. 


\section{OFFICIAL USE ONLY}

At Folkston, du Pont has taken hundreds of samples, which show a total content of about $1,600,000$ tons of heavy minerals, and a monazite tenor of about 1 percent in the heavy-mineral fraction. This gives a monazite reserve of about 16,000 tons for this ore body.

Eastern North Carolina

Probably the most prominent Pleistocenescarp on the Atlantic coast runs from west of Norfolk。 Va 。 southward into North Carolina (fig. 2) and almost entirely across the eastern part of that state。 It appears typically on the following older maps published at a 1:62,500 scale: Smithfield, $\mathrm{Va}_{0}$, Suffolk, Va。 Beckford $N_{0} C_{0}$, and Edenton, $N_{0} C_{0}$, but it is much better portrayed on the new 1:24,000 Aurora Arapahoe, and Upper Broad Creek quadrangles in North Carolina.

On the last two maps, there is a broad expanse of country to the west at an altitude of about 30 to 35 feet. Eastward, there is a comparatively rapid sise to about 40 feet (and to 50 or 60 feet farther north). from which level the scarp descends rapidly to the lower。 flat country generally less than 20 feet high。 The high crest might be interpreted as an old barrier beach or as a beach ridge: borings have shown that it is made up largely of sand, whereas the flat country to the west is underlain by typical unsorted Pleistocene sediments. The sandy crest includes at least two deposits of commercial or near-commercial grade, Belvidere and Aurora。

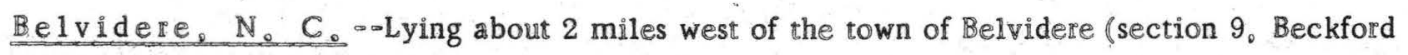
quadrangle) is an ore body about $21 / 2$ miles long and $3 / 4$ mile wide. Ten auger holes and 5 jet - drilled holes are the basis for an estimated $1,000,000$ tons of heavy minerals, the heavy $\circ$ mineral tenor being about 5 percent. Only one grain count is at present available: this only indicates that monazite is present It is reported that National Lead has re-drilled this ore body intensively。 and they probably have more exact figures for monazite content. 


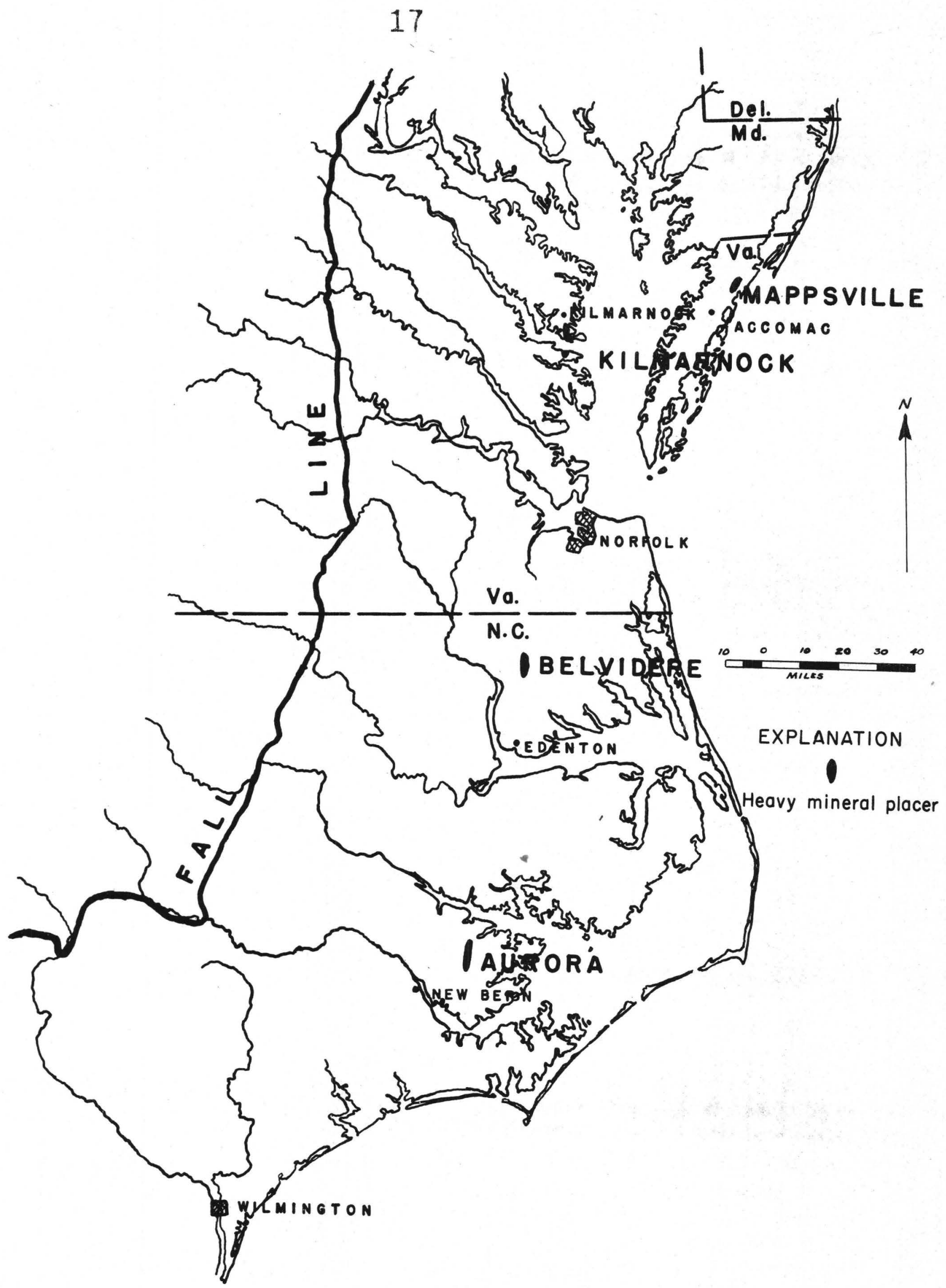

FIGURE 2. COASTAL PLAIN--MARYLAND TO NORTH CAROLINA 


\section{OFFICIAL USE ONLY}

Aurora, N, C $\rightarrow$ Along the crest of the scarp, beginning west of the town of Aurora (Aurora quadrangle) and running for some 10 miles to the south is an ore body of large size. It is about $11 / 2$ miles wide in the north and $3 / 4$ mile in the south and averages about 20 feet in depth. It was defined by 15 auger holes and 5 jet-drilled holes. The total tonnage is about $3,000,000$ tons of heavy minerals, and the heavy-mineral tenor about 3 percent. Two grain counts available at present give an average of about 0.3 percent of monazite in the heavy minerals, or about 9,000 tons of monazite in the ore body。 Again it is locally reported that National Lead has done extensive work in this area, and that they are acquiring rights to mine; undoubtedly they have more reliable figures for monazite content.

\section{Adams Run, South Carolina}

On the Edisto Island quadrangle, $1: 62,500$ or $1: 50,000$, an old shore-line feature reaching a maximum altitude of about 40 feet appears near the town of Adams Run: this feature has almost the same trend as the present shore, shown in the southeast corner of the map. Fifteen holes, 4 of them jet-drilled, have revealed the presence of an ore body south and southwest of the town. Samples show a heavy-mineral tenor of almost 5 percent, which indicates a total of about $1,000,000$ tons of heavy minerals. From two grain counts, one by du Pont and one by this project. monazite tenor is 0,2 percent and 0.0 percent respectively。 These conflicting figures serve only to indicate that the percentage of monazite in this ore body is probably very low。

$$
\text { Mappsille, Virginia }
$$

This placer, as well as the Kilmarnock deposit described below, perhaps should not be listed as a "potential ore body" well outlined. But in view of the fact that it and Kilmarnock open up an area hitherto untested they are included in this category。

The Mappsville placer is shown on the Mappsville, $\mathbb{V}_{2}, 1: 25,000$ quadrangle, in the north-central portion of the map, between Modest. Town and Mappsville School. The feature in which it lies is poorly defined on the map, although this may be a result of the inadequate contour interval. Three samples 
examined so far show a heavy-mineral content of $3,3,4,4$, and 5,0 percent, which indicates an ore of potentially commercial grade, so far as total heavy-mineral content is concerned The extreme rounding of the heavy minerals suggests a dune origin for the ore body. No monazite was seen in the three samples examined。

Kilmarnock, Virginia

The Kilmarnock placer lies on the Kilmarnock。Va, 1:62,500 quadrangle, from near Dunton Mill。 to somewhat west of Amburg. Apparently it was about 9 miles in length, but has been cut by the Rappahannock River into two parts, the northern one about 3 miles long, the other about 2 miles. At least in the northern part, the placer follows a rather well-marked topographic feature, which led to its discovery。

Fifteen samples examined so far give an average heavy mineral content of between 3.5 and 4 percent, approaching commercial grade. The placer has not been outlined fully, but a rough estimate gives a content of about 500,000 tons of heavy minerals Monazite is either lacking or present as a trace only。

\section{DEPOSITS OF QUESTIONABLE VALUE}

\section{Pleistocene terraces}

The deposits of commercial or near-commercial tenor, described above, are all surface or near-surface concentrations of heavy minerals (placers) within elongate bodies of cleanly washed sand。 They have been found at various elevations from near present sea level to over 200 feet at Trail Ridge. The typical Pleistocene "terrace" , on the other hand, is a flat, often featureless surface underlain by an essentially unsorted mixture of materials which range in grain size from pebbles to clay. Such unsorted materials underlie a very large part of the outer half of the Coastal Plain, at various elevations up to about 300 feet. 
But occasionally, fairly clean sands, often cross-bedded, occur wirhin the largely unsorted sediments. At a few localities these sands enclose small lenses which are very rich in heavy minerals。 It is possible that larger bodies of such sand, with a high tenor of heavy minerals, may be found, but it is considered unlikely. The only favorable factor is that almost no search for this type of deposit has been made: no one has been willing to hand-auger or jet-drill through silt and clay in the search for what appears to be an exceedingly small and rare type of deposit。 Our few samples from such local heavy mineral lenses show very low or no monazite content。

\section{Placeis of $10 \mathrm{w}$ tenol}

Widely distributed throughout the Coastal Plain are sand bodies ranging in tenor from the " value $^{\circ}$ of about 0.5 percent to around 1 or 2 percent. Du Pont has found many such bodies, a considerable number have turned up in the progress of our work。 and Cannon (1950, p。205) says that several large bodies containing about 2 percent are known. The cut off point today in commercial operations is around 4 percent, so that few of these sub-marginal placers have been outlined or studied in detail. There is one important question about these placers: in the future, will new methods of mining and separation, or new uses for the minerals make it possible to work these bodies economically? Such deposits are of unpredictable value for potential production of monazite. so far as the present evidence goes. Seventeen samples from non-commercial placels containing more than 0,5 percent heavy minerals give monazite percentages in heavy minerals ranging from 0.0 to 2,0 percent, and there seems to be no clear correlation between heavy-mineral tenor and that of monazite within the heavy minerals。

\section{Recent beaches and dunes}

Recent features, or those very close to the present shore line, are almost all made up of clean sand; the problem then is to find in these sands, deposits of high enough tenor and sufficient tonnage to form ore bodies. In Florida, such near shore or actual shore features have been worked for a long time, but on a 
small scale. Du Pont and probably National Lead have explored the shore line from Virginia south to Florida and around the tip of Florida to the Gulf of Mexico. Du Pont has turned up a large number of deposits of interest, but in each case the volume has been too small or the titania content of the sand has been too low for commercial operations.

Our information on distribution, grade, and tonnage of monazite is rather meager. Two grain counts by du Pont and 10 of our own show that monazite tenor in such recent features is only about a trace in the total heavies, but additional samples, still to be studied may modify this conclusion. The one exception, a single sample from Myrtle Beach, $S_{\circ} C_{0}$, which contained about 1 percent monazite, can be explained. It is known from other evidence that at least part of the beach sand here is being supplied by the erosion of Cretaceous bedrock. This bedrock, though under the ocean and not available for sampling, probably contains a small percentage of monazite, which is being concentrated on the beach.

\section{Recent stieam deposits}

In this report, only the streams in about the eastern half of the Coastal Plain are considered。 This is done specifically to exclude streams near the Fall Line, or those within or near Coastal Plain formations like the Tuscaloosa or McBean, which are known to contain considerable monazite. With such restrictions, our sampling, though limited to some tens of samples, shows disappointingly small amounts or no monazite at all in flood-plain deposits or in material now being transported. It is difficult to obtain samples from most of the streams. Most of them have very low gradients, flow through swamps, and are approachable at only a few points. We did not collect a bottom sample of what the streams are now carrying, but only sand from nearsshore bars or from flood deposits on the banks, or from the flood plains, and these are the very parts of the bed load that would be expected to be low or barren of monazite. The tecent stream sediments of this area, then, we regarded as unpromising, but as virtually unsampled in a way to reveal the presence of monazite。 


\section{SIGNIEICANCE OF TITANIA CONTENT OF ILMENITE}

This report is concerned primarily with byproduct monazite in commercial or near-commercial placers. Since titania $\left(\mathrm{TiO}_{2}\right)$ from ilmenite is by far the most valuable product from present operations. variation in titania content may be the decisive factor in the operation or neglect of a given placer。 For example, we are told that du Pont would have gone into production in eastern North Carolina if titania content (about 58 percent) had been as high or almost as high as the 61 percent in their Trail Ridge workings. So the amount of titania in ilmenite may control the production of monazite in a given area.

The problem has been discussed in detail by Cannon (1950, p。204,208-210)。 He states that ilmenite increases in titania content from north to south along the Coastal Plain, both in recent beach and stream deposits, and in the older shore-line features. Thousands of analyses show that detrital ilmenite in Florida has a content of around 60 percent. On the other hand it is generally accepted (we do not know with what proof) that in Virginia, or Maryland, or New Jersey。 ilmenite would tend to approach its "normal" composition of around 53 percent titania. This difference in composition is a very important one, though not the onlly reason why heavy-mineral exploration and production have been concentrated in the southeasternmost part of the Coastal Plain.

The placers in eastern North Carolina are potential ore bodies not only because of their total tonnage, but because their ilmenite contains about 56 to 58 percent of titania, which is to be contrasted with a figure of 55 percent for an average of 9 samples reported by du Pont from low-level Pleistocene features and from recent beaches of the same general area. It is possible that a figure less than 55 percent would be found in more northerly deposits of the same character. The application of this general rule of titania variation with geographic position is of particular interest in connection with the Kilmarnock placer。 as will be discussed later.

One more aspect should be mentioned: the whole problem of titania content of ilmenite, from the factual data expressed as percentages, through geographic distribution of values, to the causes of the variation $_{0}$ form one integrated line of research which gives promise of valuable scientific and economic 
results. So far, this project has no additional data which contribute to the solution of this problem. but we have sampled wide areas with it in mind. We would like to find out when and where the ilmenite changed from the normal type found in crystalline rocks to the high-titania type important in present ore bodies Did it change during formation of saprolite in the southeastern Piedmont, or while being transported to the deposit in which it is found? Is it lower in value in the older rocks of the Coastal Plain. increasing in value in successively younger formations? Can a definite titania content be used as proof of derivation from a definite source? If an answer can be found to these questions we may have another clue to the source of heavy minerals in the various ore bodies. If the concept of geographic variation can be validated and extended. It may be possible to be much more definite about the chances of getting byproduct monazite in a given area of the coastal plain.

TYPES OF HEAVY MINERAL SUITES PRESENT

Apart from several papers on heavy minerals of recent beach sands and a very few on older sediments to the north, the dearth of heavy -mineral information for most of the Coastal Plain is almost complete. It is this lack of information which has led several writers to guess that heavy minerals in ore bodies or other placers might have come either directly from the Piedmont, or might have been for a while incorporated in one or more Pleistocene or older sediments, from which they were subsequently eroded. In view of the magnitude of the task, it is perhaps not surprising that no one tried to find out whether the Coastal Plain formations were capable of furnishing the minefals in question. The writers have had a chance to travel widely, and to examine and collect from most of the Coastal Plain from Maryland to Florida. The information which follows is based on preliminary examination of some 400 heavy mineral $^{2}$ slides. 
"Older" and "younger" suites

In comparing the Trail Ridge suite of heavy minerals with those of the Atlantic beaches and other Atlantic near-shore or low-level sand bodies, Cannon (1950,p。207-209) found that the Trail Ridge suite was exceptional in that ir lacked three common minerals: epidote, hornblende, and garnet. Because he found a similar lack in shore sands along the Gulf of Mexico, he called this a "Gulf suite" , and the other. containing the three minerals, and "Atlantic suite" . This led him further to postulate that the Trail Ridge ore body must have been formed by transportation of sediment from a western。 or Gulf, distributive province.

Our work shows that, at least from North Carolina to Florida, and including southeastern Alabama, Cannon"s "Gulf suite" is typical of, and found in almost every one of the Coastal Plain formations from Cretaceous through Tertiary, and in the higher, older parts of the Pleistocene as well, For that reason, we propose to call it here the ${ }^{\circ}$ older" suite $^{\circ}$ This suite typically contains 50 to 90 percent of opaque minerals, of which ilmenite is the dominant mineral and leucoxene the subordinate。 In addition, zircon and tourmaline are always present, zircon usually more abundant。 Rutile is almost always present as a minor constituent. Staurolite, kyanite, and sillimanite are present in various proportions, though one or more of them may be missing locally。 Percentages vary, and inexplicable occurrences or absences may be encountered, but this basic suite is found over and over again. somewhat too monotonously. Monazite is often present in small amount, but we propose to treat its occurrence in a later and more detailed report。

In sharp contrast with this "older" suite, is that found in Atlantic beach sands. The difference consists in the presence of epidote, homblende, and garnet, often in large quantity。 One, or occasionally two of these species may be missing locally, but typically they are all present. Cannon called this his "Atlantic suite". This name might be retained, but in view of the fact that all of the Atlantic Coastal Plain is in some sense "Atlantic". We propose to call this the "younger" suite. 


\section{Vertical range of the two suites}

One of the most surprising results of our work has been the discovery that the "older" suite, while typical of the older formations and of the Pleistocene terraces at high altitude, gives way to the "younger" suite at low elevations. Any Pleistocene, sorted or unsorted, at 200 feet, 100 , or at 75 feet has yielded the restricted "older" suite。Any recent beach, and any deposit of whatever age, below about 50 feet yields a "younger" suite.

The exact, if it is exact, elevation at which this change takes place has not been determined as yet. But the real enigma, is the reason for the peculiar distribution pattern of the two suites。 We can only speculate about this at present. giving more of a description than an explanation。

It looks as though during Cretaceous, Tertiary, and most of Pleistocene time, the Piedmont failed to yield epidote, hornblende, and garnet to the sediments being deposited then, perhaps because of deep

2 . 3 , weathering of the crystalline rocks or because the source rocks for these minerals were covered。 Or perhaps the minerals were deposited in the sediments in question, but were subsequently leached out Late in Pleistocene time, assuming the first explanation to be the more probable one, streams began to carry the three minerals out to the coastal areas and into estuaries and re-entrants in the older rocks, thus yielding a "younger ${ }^{\circ 0}$ suite。 Our samples of present-day stream sediments show, as a general rule, rather large quantities of epidote, hornblende, and garnet, Hence, a considerable, if not the major part of these sediments must have been derived directly from the Piedmont. Recent beach sands, likewise containing these three minerals in quantity, therefore seem to have been furnished in large part by stream sediments, and not to any major degree by efosion of older Coastal Plain formations, Going back in time from the present, the same conditions seem to have obtained during deposition of the low-altitude Pleistocene terrace formations those lying below 50 or 60 feet above present sea level.

It would be of great interest if monazite were restricted in occurrence to one or the other of the two suites, for that might facilitate search for it But the present information indicates that it occurs without regard to type of suite. 


\section{OFEICIAL USE ONLY}

APPLICATIONS OF TITANIA CONTENT AND TYPE OF SUITE

\section{Eastern North Carolina}

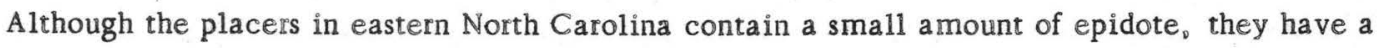
heavy-mineral suite quite similar to that at Trail Ridge。 The titania content, also, is unusually high for such a northerly deposit, although still a good bit lower than in Florida. These two facts have led some, notably Cannon (personal communication), to assume a rather close connection between the North Carolina and Trail Ridge ore-forming processes. In "Trail Ridge time", according to this idea, a practically continuous coastal sand belt extended from Florida to at least North Carolina. This sand contained a more or less uniform suite; the ilmenite in it had a fairly uniform content of titania, although somewhat lower in the north than in the south. Later。 possibly when the (Surry) scarp was formed at about 90 to 100 feet above sea leve1. most of this sand belt and its contained minerals were eroded and washed away: only Trail Ridge and the linear belt in North Carolina were preserved. Still later; re-working and re-shaping took place, at the time the prominent scarp of the area was cut, and these processes gave us the sand ridge and the ore bodies at Belvidere and Aurora。

It is now evident that similarity of North Carolina and Trail Ridge suites does not necessarily involve a close genetic connection: both are essentially ${ }^{\circ}$ older ${ }^{\circ 2}$ suites. The meaning of the high titania in the North Carolina suite is not clear at present.

\section{Kilmarnock potential ore body.}

Earlier in the work of the project it was believed that the Kilmarnock placer might be a northern extension of the supposed Trail Ridge-Eastern North Carolina trend. At Kilmarnock, epidote, hornblende, and garnet are present, but in smaller amounts than is typical for the ${ }^{\circ}$ younger ${ }^{\circ 0}$ suite. In addition, these minerals had already appeared at Belvidere and Aurora in North Carolina, so it was not surprising that they should increase in percentage to the north: indeed the distinction between "older" and "younger" suites 


\section{OFFICIAL USE ONLY}

may not hold north of North Carolina. Further, in a test of two samples from Kilmarnock, one showed low titania content in ilmenite, but the other gave a value of about 56 percent. This value is presumably higher than that of beach sands and stream sediments in Virginia, but its significance is not known.

At present it is not clear if there is any correlation between type of suite and percentage of titania in ilmenite.

\section{1 SIG NIFICANCE OF KILMARNOCK AND MAPPSVILLE PLACERS}

The Kilmarnock and Mappsville placers, in widely separated parts of the Virginia Coastal Plain, have a significance beyond their possible economic value: they show the existence of sand bodies of considerable size, with a heavy-mineral tenor near or within the commercial range, something the companies seem to have discounted so far to the north.

The one sample with a titania content of 56 percent at least opens the possibility that ilmenite in the northern part of the Coastal Plain may be of commercial titania tenor. Assumed low tenor to the north has been perhaps the chief reason why company exploration has been limited to the southern states. Further study of our samples may prove their assumption to be wrong and may open large areas of the Coastal Plain in Virginia, Maryland Delaware, and New Jersey to commercial exploration.

The Kilmarnock and Mappsille placers are disappointing in that they contain either only a trace, or no monazite at all. We do not regard this as proof or even as an indication that monazite will not be found in northern placers, In a negative way, it may be pointed out that the Adams Run, $\mathrm{S}_{0} \mathrm{C}_{0}$, potential ore body contains virtually no monazite, similar to the deposit at Trail Ridge。 Looked at in the other way, we know that there are monazite-bearing crystalline rocks around Philadelphia and Wilmington。 Del, ; Mertie has reported them near Fredericksburg, $\mathrm{Va}_{0}$, and although we have made no search for them in between these places, the same kinds of rocks are continuous. Further ${ }_{0}$ we have found significant quantities of monazite in the basal Cretaceous (Patuxent) in Delaware, Maryland, and Virginia, as well as in the beach sand at Stingray Point, $\mathrm{Va}_{\mathrm{o}}$, on Chesapeake Bay。 We do not believe and do not mean to imply that the total amount 


\section{OFFICIAL USE ONLY}

of monazite in either the crystalline rocks or in the sediments will prove to be as great in the north as farther south. But we see no reason why monazite should not be found in byproduct quantities in northern placers。

\section{OUTLOOK FOR THE FUTURE}

It is obviously difficult to give any credible number to the ore bodies that still remain undiscovered. But the number and spacing of exploratory holes put down in promising topographic features still leave the probability of finding an additional number of placers. Several of the known ore bodies have a width of from half a mile to a mile or so, and in many cases and many areas, auger holes have been spaced at distances of this magnitude. The chances of missing a placer are good, as almost happened at Folkston。 and it would probably pay to re-work a great deal of the already explored area.

There is encouragement, also, in the fact that both Yulee and Folkston have been discovered within the last few months, one of them at an elevation which had not previously yielded ore.

At the present time the heavy-mineral industry of the area is expanding Du Pont will open operations at Yulee and Folkston, producing monazite as a byproduct, and although we do not know National Lead's plans, they are reported to be acquiring land to develop eastern North Carolina, also a monazite producer。

Recently, the writers have been approached by geologists of the Bear Creek Mining Company (subsidiary of Kennecott Copper), who are looking into the possibility of entering the heavy-mineral field in the southeast. In addition, there are a considerable number of smaller operators or prospectors, principally in Florida, who are constantly on the search for new deposits. The industry seems to be healthy, and monazite production should increase during the next few years. Reserves or impending production of about 32. 000 tons of monazite have been reported elsewhere in this report. 


\section{OFFICIAL USE ONLY}

29

\section{LITERA TURE CITED}

Beasley, A. W. 1948, Heavy mineral beach sands of southern Queensland: Royal Soc. Queensland Proc。, v. 59, po 109-139.

Cannon, H。 B. 1950, Economic minerals in the beach sands of the southeastern United States: In Symposium on Mineral Resources of the southeastern United States, Knoxville, Tenn。 , p. 202-210。

Flint, R。 F。 1940, Pleistocene features of the Arlantic Coastal Plain: Am. Jour. Sci., v. 238, p. $757-787$.

Martens, J. H。C. 1935, Beach sands between Charleston, South Carolina, and Miami, Florida: Geol. Soc. America Bull。, v. 46, p. 1563-1596.

Mertie, J。 B.. Jr。, 1949, Monazite: In Industrial Minerals and Rocks, New York。 N. Y. p. 629-636. . 1953, Monazite deposits of the southeastern Atlantic States: U. S. Geol. Survey

Circ。237.

\section{UNPUBLISHED REPORT}

Mertie, Jo $B_{0} 。 J_{0}, 1951$, Heavy minerals in the Pleistocene terraces of South Carolina and Georgia: U。 S。 Geol. Survey Trace Elements Memo. Report 23. 